\title{
Haloarcula quadrata sp. nov., a square, motile archaeon isolated from a brine pool in Sinai (Egypt)
}

\author{
Aharon Oren, ${ }^{1}$ Antonio Ventosa, ${ }^{2}$ M. Carmen Gutiérrez ${ }^{2}$ \\ and Masahiro Kamekura ${ }^{3}$
}

Author for correspondence: Aharon Oren. Tel: +972 26584951. Fax: +972 26528008.
e-mail: orena@shum.cc.huji.ac.il

\author{
${ }^{1}$ Division of Microbial and \\ Molecular Ecology, \\ Institute of Life Sciences \\ and the Moshe Shilo \\ Center for Marine \\ Biogeochemistry, The \\ Hebrew University of \\ Jerusalem, Jerusalem \\ 91904, Israel \\ 2 Department of \\ Microbiology and \\ Parasitology, Faculty of \\ Pharmacy, University of \\ Seville, Seville 41012, Spain \\ 3 Noda Institute for \\ Scientific Research, 399 \\ Noda, Noda-shi, Chiba-ken \\ 278-0037, Japan
}

\begin{abstract}
The motile, predominantly square-shaped, red archaeon strain 801030/1', isolated from a brine pool in the Sinai peninsula (Egypt), was characterized taxonomically. On the basis of its polar lipid composition, the nucleotide sequences of its two 165 rRNA genes, the DNA G+C content $(60.1 \mathrm{~mol} \%)$ and its growth characteristics, the isolate could be assigned to the genus Haloarcula. However, phylogenetic analysis of the two 165 rRNA genes detected in this organism and low DNA-DNA hybridization values with related Haloarcula

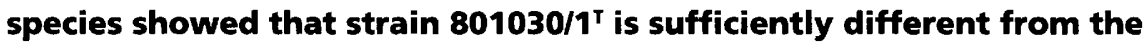
recognized Haloarcula species to warrant its designation as a new species. A new species, Haloarcula quadrata, is therefore proposed, with strain 801030/1 (= DSM 11927') as the type strain.
\end{abstract}

Keywords: Haloarcula quadrata, square bacteria, archaea, halophile

\section{INTRODUCTION}

Square bacteria were first observed in 1980 by Walsby in the Gavish Sabkha, a coastal brine pool in the Sinai peninsula, Egypt (Parkes \& Walsby, 1981; Walsby, 1980). Walsby recognized these extremely thin, squareshaped structures as prokaryotes due to the presence of refractile gas vacuoles. Square bacteria have since been reported to occur in many thalassohaline hypersaline environments in which the salt concentration exceeds $200-250 \mathrm{~g} \mathrm{l}^{-1}$, and up to $\mathrm{NaCl}$ saturation. These include saltern crystallizer ponds in Israel (Oren, 1994; Oren et al., 1996), Spain (Guixa-Boixareu et al., 1996; Torrella, 1986), San Francisco Bay (USA) and Baja California (Mexico) (Javor et al., 1982; Stoeckenius, 1981).

The gas-vacuole-containing type of square bacteria observed by Walsby has never been obtained in culture. A single report of the successful isolation of

\footnotetext{
Abbreviations: PG, PGP, PGS, the diether derivatives of phosphatidylglycerol, the methyl ester of phosphatidylglycerophosphate and phosphatidylglycerosulfate, respectively; TGD-2, 1-O-[ $\beta$-D-glucose- $\left(1^{\prime} \rightarrow 6^{\prime}\right)-$ $\alpha$-D-mannose-(1' $\left.\rightarrow 2^{\prime}\right)-\alpha$-D-glucose]-2,3-di-O-phytanyl-sn-glycerol.

The DDBJ accession numbers for the 165 rRNA sequences of strain $801030 / 1^{\top}$ are $A B 010964$ and $A B 010965$.
}

this type of bacterium from a Spanish saltern was published by Torrella (1986). Unfortunately, this isolate has not been deposited in a culture collection and the culture was lost many years ago. Other attempts to isolate this intriguing type of prokaryote from a variety of hypersaline environments (the Gavish Sabkha, salterns of Guerrero Negro, Baja California and San Diego, California) led to the isolation of 'boxshaped' pleomorphic red halophilic archaea, lacking gas vacuoles, which were classified in the genus Haloarcula on the basis of their polar lipid composition and 16S rRNA nucleotide sequences. These strains (species incertae sedis 'Haloarcula sinaiiensis' and 'Haloarcula californiae') (Javor et al., 1982) still await a more detailed characterization in order to define their taxonomic position. The triangular and rhomboid cells of Haloarcula japonica (Takashina et al., 1990) show some morphological similarity to these isolates.

Early isolation experiments yielded a motile, square bacterium from the Gavish Sabkha. This strain, which lacks gas vacuoles, was designated $801030 / 1^{\mathrm{T}}$. Its morphological characteristics and its interesting mode of motility were reported by Alam et al. (1984). Cells may possess a single flagellum or several flagella anchored from a single or from several locations on the 
cell surface. Several filaments may form a stable bundle that does not fall apart when changing from clockwise to anti-clockwise movement and vice versa. Instead of the three flagellar proteins present in flagella of Halobacterium, SDS-PAGE of isolated flagella of strain $801030 / 1^{\mathrm{T}}$ showed the presence of a single flagellin band with an apparent molecular mass of $73 \mathrm{kDa}$.

We have performed a taxonomic characterization of the square motile strain $801030 / 1^{\mathrm{T}}$. On the basis of its growth characteristics, its polar lipid composition and the nucleotide sequences of its 16S rRNA genes, the isolate could be assigned to the genus Haloarcula. However, based on phylogenetic analysis of the two different 16S rRNA genes detected in this organism and the low DNA-DNA hybridization values with the other Haloarcula species, the isolate is sufficiently different from the recognized Haloarcula species to warrant its designation as a new species.

\section{METHODS}

Bacterial strains. A culture of isolate $801030 / 1^{\mathrm{T}}$ (Alam et al., 1984) was kindly supplied by M. Kessel (Bethesda, MD, USA). For comparison, reference strains of halophilic archaea were included in this study, as listed in Table 1.

Cultivation conditions. The standard growth medium used for strain $801030 / 1^{\mathrm{T}}$ and other Haloarcula strains (Oren et al., 1988) contained (in gl ${ }^{-1}$ ): $\mathrm{NaCl}, 206 ; \mathrm{MgSO}_{4} .7 \mathrm{H}_{2} \mathrm{O}, 36$;
$\mathrm{KCl}, 0.373 ; \mathrm{CaCl}_{2} .2 \mathrm{H}_{2} \mathrm{O}, 0.5 ; \mathrm{MnCl}_{2}, 0.013 \mathrm{mg} \mathrm{l}^{-1}$; and yeast extract, $5(\mathrm{pH} 7)$. Other halophilic archaea used as reference strains were grown in this medium or other suitable media, as required. The growth medium was modified with respect to salt concentration, yeast extract content, addition of other nutrients, buffers, antibiotics, etc., as specified in the experiments. For growth experiments at different $\mathrm{pH}$ values, the buffers MES (in the $\mathrm{pH}$ range 5.0-5.5), PIPES (pH 6-7) and HEPES ( $\mathrm{pH} 7 \cdot 5-9 \cdot 0)$ were added at a final concentration of $25 \mathrm{mM}$. These strains were routinely grown with shaking at $35^{\circ} \mathrm{C}$ in 100 or $250 \mathrm{ml}$ Erlenmeyer flasks containing 30 or $100 \mathrm{ml}$ medium, respectively. Growth was assessed by measuring the $\mathrm{OD}_{600}$ of the cultures.

Phenotypic characterization. Unless specified otherwise, tests for phenotypic properties were carried out as indicated in the proposed minimal standards for the description of new taxa in the order Halobacteriales (Oren et al., 1997). Degradation of Tween and gelatin was tested as recommended by Gutiérrez \& González (1972). Appropriate positive and negative controls were included in all tests performed.

Formation of acids from different sugars was tested in media in which the yeast extract concentration was reduced to 1.0 or $0.5 \mathrm{~g} \mathrm{l}^{-1}$, amended with $0.5 \mathrm{~g} \mathrm{NH}_{4} \mathrm{Cl}^{-1}$ and $5 \mathrm{~g}$ of the sugar tested $1^{-1}$ (autoclaved separately). To examine growth stimulation by sugars and other compounds, this medium was buffered at $\mathrm{pH} 7.0$ by including $20 \mathrm{mM}$ PIPES. To test for the ability of single carbon sources to support growth, yeast extract was omitted, and the compound to be tested was added at a concentration of $5 \mathrm{~g} \mathrm{l}^{-1}$, together with $1 \mathrm{~g}$ $\mathrm{NH}_{4} \mathrm{Cl} \mathrm{l}^{-1}$ and $0.05 \mathrm{~g} \mathrm{KH}_{2} \mathrm{PO}_{4} \mathrm{l}^{-1}$ and $20 \mathrm{mM}$ PIPES. The outcome was considered positive when growth was obtained in at least four successive transfers in this medium.

Growth and gas formation with nitrate as electron acceptor were tested in $100 \mathrm{ml}$ glass-stoppered bottles completely filled with growth medium to which $5 \mathrm{~g} \mathrm{NaNO}_{3} \mathrm{l}^{-1}$ was

Table 1. DNA relatedness among strain $801030 / 1^{\top}$ and other halophilic archaea studied

DNA-DNA relatedness values are mean results of at least three independent determinations, which generally did not differ by more that $5 \%$. ${ }^{\mathrm{T}}$, Type strain.

\begin{tabular}{|c|c|}
\hline Organism & $\begin{array}{l}\text { Percentage hybridization with } \\
{ }^{3} \mathrm{H} \text {-labelled DNA from strain } 801030 / 1^{\mathrm{T}}\end{array}$ \\
\hline Haloarcula strain $801030 / 1^{\mathrm{T}}$ & 100 \\
\hline Haloarcula vallismortis ATCC $29715^{\mathrm{T}}$ & 20 \\
\hline Haloarcula marismortui ATCC $43049^{\mathrm{T}}$ & $<10$ \\
\hline Haloarcula hispanica ATCC $33960^{\mathrm{T}}$ & 22 \\
\hline Haloarcula japonica JCM $7785^{\mathrm{T}}$ & 34 \\
\hline Haloarcula argentinensis ATCC $29841^{\mathrm{T}}$ & 14 \\
\hline Haloarcula mukohataei DSM 11483 & $<10$ \\
\hline 'Haloarcula sinaiiensis' ATCC 33800 & $<10$ \\
\hline Haloferax gibbonsii ATCC $33959^{\mathrm{T}}$ & 18 \\
\hline Haloferax volcanii $\mathrm{NCIMB} 2012^{\mathrm{T}}$ & $<10$ \\
\hline Haloferax mediterranei ATCC $33500^{\mathrm{T}}$ & $<10$ \\
\hline Halobacterium salinarum DSM $3754^{\mathrm{T}}$ & 18 \\
\hline Halorubrum saccharovorum ATCC $29252^{\mathrm{T}}$ & 15 \\
\hline Halorubrum lacusprofundi DSM 5036 & $<10$ \\
\hline Halorubrum sodomense ATCC $33755^{\mathrm{T}}$ & $<10$ \\
\hline Halorubrum distributum JCM $9100^{\mathrm{T}}$ & $<10$ \\
\hline Halobaculum gomorrense DSM $9297^{\mathrm{T}}$ & $<10$ \\
\hline Natrialba asiatica JCM $9576^{\mathrm{T}}$ & $<10$ \\
\hline
\end{tabular}


added and which included an inverted test tube to observe the formation of gas. Anaerobic growth in the presence of $5 \mathrm{~g} \mathrm{~L}$-arginine. $\mathrm{HCl} \mathrm{I}^{-1}$ was tested in completely filled $25 \mathrm{ml}$ stoppered tubes. Controls without nitrate or arginine were included and all incubations were performed in the dark. Haloarcula marismortui was used as a positive control for the formation of nitrite and gas from nitrate, and Halobacterium salinarum served as a positive control for anaerobic growth on arginine.

Polar lipid characterization. Cell pellets from $20 \mathrm{ml}$ culture were suspended in $1 \mathrm{ml} 4 \mathrm{M} \mathrm{NaCl}$ and extracted with $3.75 \mathrm{ml}$ methanol/chloroform $(2: 1, \mathrm{v} / \mathrm{v})$ for $4 \mathrm{~h}$. The extract was centrifuged and the pellet was re-extracted with $4.75 \mathrm{ml}$ methanol/chloroform/water $(2: 1: 0 \cdot 8, \mathrm{v} / \mathrm{v})$. Chloroform and water $(2.5 \mathrm{ml}$ each) were added to the combined supernatants to achieve phase separation and, after centrifugation, the chloroform phase was collected and dried in a vacuum desiccator. Lipids were redissolved in a small volume of chloroform, applied to silica gel plates $(20 \times 20 \mathrm{~cm}$; Sigma $)$ and separated by single development with chloroform/methanol/acetic acid/water $(85: 22 \cdot 5: 10$ $: 4, \mathrm{v} / \mathrm{v})$. Lipid spots were detected by spraying with the following reagents: $0.5 \% \alpha$-naphthol in $50 \%$ methanol, followed by $5 \% \mathrm{H}_{2} \mathrm{SO}_{4}$ in ethanol, and heating of the plates at $150{ }^{\circ} \mathrm{C}$ (allowing detection of glycolipids); $0 \cdot 2 \% \mathrm{CeSO}_{4}$ in $0.5 \mathrm{M} \mathrm{H}_{2} \mathrm{SO}_{4}$, followed by heating at $150{ }^{\circ} \mathrm{C}$ (a general lipid stain, allowing differentiation of glycolipids from other lipids by colour); and ammonium molybdate/sulfuric acid reagent (for the detection of phospholipids) (Oren et al., 1996; Torreblanca et al., 1986).

Extraction of genomic DNA and determination of DNA base composition. Cells were harvested, washed in $25 \% \mathrm{NaCl}$ and suspended in $0 \cdot 15 \mathrm{ml} \mathrm{NaCl} / 0 \cdot 1 \mathrm{M}$ EDTA buffer, $\mathrm{pH} 8 \cdot 0$. Lysis was accomplished at $60^{\circ} \mathrm{C}$ for $10 \mathrm{~min}$ after adding SDS at a final concentration of $2 \%(w / v)$. The DNA was extracted and purified by the method of Marmur (1961). The purity was assessed from the $A_{260} / A_{280}$ and $A_{230} / A_{260}$ ratios (Johnson, 1994).

The DNA $\mathrm{G}+\mathrm{C}$ content was determined from the midpoint value $\left(T_{\mathrm{m}}\right)$ of the thermal denaturation profile (Marmur \& Doty, 1962) in $0.1 \times \mathrm{SSC}$ buffer $(0.15 \mathrm{M} \mathrm{NaCl}$ buffered with $0.015 \mathrm{M}$ trisodium citrate, $\mathrm{pH} 7.0$ ) and was obtained with a Perkin-Elmer UV-Vis 551S spectrophotometer at 260 $\mathrm{nm}$. The instrument was programmed for temperature increases of $1.0^{\circ} \mathrm{C} \mathrm{min}^{-1}$. The $T_{\mathrm{m}}$ was determined by a graphic method described by Ferragut \& Leclerc (1976) and the $\mathrm{G}+\mathrm{C}$ content was calculated from this temperature by using the equation of Owen \& Hill (1979). The $T_{\mathrm{m}}$ value of reference DNA from Escherichia coli NCTC 9001 was taken as $74.6{ }^{\circ} \mathrm{C}$ in $0.1 \times \mathrm{SSC}$ (Owen \& Pitcher, 1985).

Preparation of labelled DNA and DNA-DNA hybridization experiments. DNA was labelled by the multiprime system with a commercial kit (RPN 1601 Y; Amersham) with deoxy $\left[1^{\prime} 2^{\prime} 5^{\prime}-{ }^{3} \mathrm{H}\right]$ cytidine $5^{\prime}$-triphosphate (Amersham). The mean specific activity obtained with this procedure was $8.4 \times 10^{6}$ c.p.m. $\mu \mathrm{g}^{-1}$ DNA. The labelled DNA was denatured prior to hybridization by heating at $100{ }^{\circ} \mathrm{C}$ for $5 \mathrm{~min}$ and then placed on ice.

DNA-DNA hybridization studies were performed by the competition procedure of the membrane method described by Johnson (1994). Competitor DNAs were sonicated (Braun) at $50 \mathrm{~W}$ for two $15 \mathrm{~s}$ time intervals. Membrane filters (HAHY; Millipore) containing reference DNA (25 $\mu \mathrm{g} \mathrm{cm}^{-2}$ ) were placed in $5 \mathrm{ml} \mathrm{screw-cap} \mathrm{vials} \mathrm{that} \mathrm{contained}$ the labelled, sheared, denatured DNA and the denatured, sheared competitor DNA. The ratio of the concentrations of competitor to labelled DNA was at least 150:1. The final volume and concentration were adjusted to $140 \mu \mathrm{l}, 2 \times \mathrm{SSC}$ and $30 \%$ formamide. Hybridization was performed for $18 \mathrm{~h}$ in a water bath (Grant Instruments) with slow shaking at $56{ }^{\circ} \mathrm{C}$, which is within the limits of validity for the filter method (De Ley \& Tijtgat, 1970), in triplicate. After hybridization, the filters were washed in $2 \times$ SSC at the optimal renaturation temperature $\left(56{ }^{\circ} \mathrm{C}\right)$. The radioactivity bound to the filters was measured in a liquid scintillation counter (Beckman Instruments) and the percentage homology was calculated according to Johnson (1994). At least three independent determinations were carried out for each experiment.

Analysis of 16S rDNA. The nucleotide sequences of the $16 \mathrm{~S}$ rRNA genes were determined as described by Kamekura \& Seno (1993).

\section{RESULTS}

Cells of the halophilic archaeon strain $81030 / 1^{\mathrm{T}}$ were predominantly square-shaped, somewhat pleomorphic, flat cells under all growth conditions tested when sufficient magnesium was present in the medium (see below). Cells measured between 2 and $3 \mu \mathrm{m}$ in diameter (Fig. 1). Gas vacuoles were never observed. Cells were motile by means of one or more flagella as documented by the dark-field microscopy pictures and electron micrographs presented by Alam et al. (1984). Cells stained Gram-negative. Colonies on agar plates were small (less than $1 \mathrm{~mm}$ in diameter, even after prolonged incubation), entire, smooth and red-orange. Oxidase and catalase reactions were positive.

As for other halophilic members of the archaea, high salt concentrations were required for growth and for stabilization of the cells. Optimum growth was observed in the presence of $3 \cdot 4-4.3 \mathrm{M} \mathrm{NaCl}$ in media containing $0 \cdot 15 \mathrm{M} \mathrm{Mg}^{2+}$ and no growth was obtained below $2.7 \mathrm{M} \mathrm{NaCl}$. At least $50-100 \mathrm{mM} \mathrm{Mg}^{2+}$ was required for optimal growth and for maintenance of the square morphology. Best growth was obtained at $\mathrm{Mg}^{2+}$ concentrations between 0.1 and $0.5 \mathrm{M}$ in medium containing in addition $3.3 \mathrm{M} \mathrm{Na}^{+}$. In the presence of

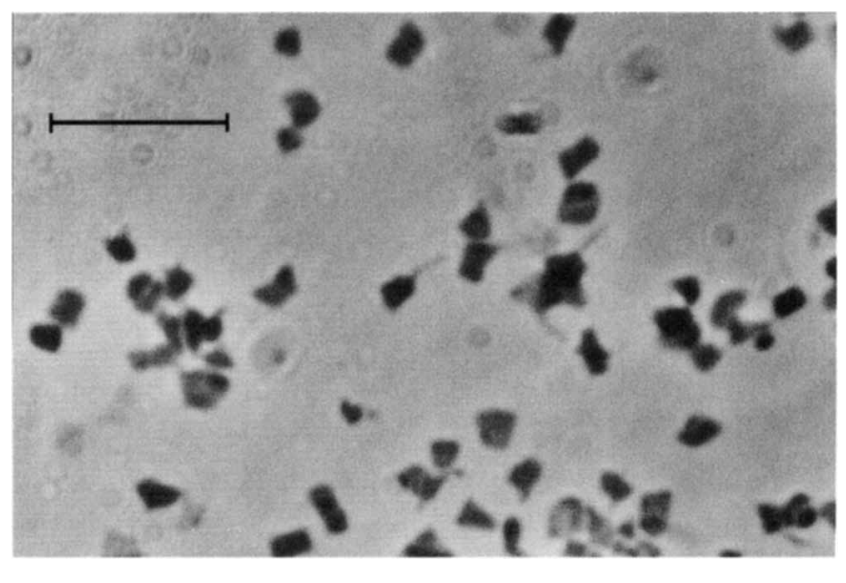

Fig. 1. Phase-contrast micrograph of a culture of strain $801030 / 1^{\top}$ in standard growth medium. Bar, $10 \mu \mathrm{m}$. 
$1 \mathrm{M} \mathrm{Mg}^{2+}$, growth was severely inhibited. When cells were suspended in $\mathrm{NaCl}$ concentrations lower than $0.5 \mathrm{M}$ and in the absence of divalent cations, immediate lysis occurred and $\mathrm{NaCl}$ concentrations as high as $3.5 \mathrm{M}$ were required to maintain the native cell shape. At intermediate $\mathrm{NaCl}$ concentrations $(0 \cdot 7-3.4 \mathrm{M})$, cells lost their native square or pleomorphic shape and turned into spheroplasts. A similar phenomenon has been reported previously in Haloarcula marismortui

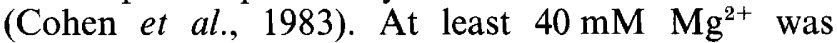
required to prevent rounding of the cells and, in the presence of $100 \mathrm{mM} \mathrm{MgCl}$, the native cell shape was maintained even when the cells were suspended in solutions lacking $\mathrm{NaCl}$.

The optimum $\mathrm{pH}$ for growth was $6 \cdot 5-7 \cdot 0$; no growth was observed below pH 5.9 and above $\mathrm{pH} \mathrm{8.0.} \mathrm{The}$ optimum growth temperature was $50-53{ }^{\circ} \mathrm{C}$; no growth was observed above $55^{\circ} \mathrm{C}$.

A number of sugars and other organic compounds stimulated growth in buffered media in which the yeast extract concentration was reduced to $0 \cdot 05-0 \cdot 10 \%$. Growth stimulation was observed by glucose, galactose, maltose, sucrose, mannitol, sorbitol, glycerol, succinate and pyruvate. Fructose, mannose, arabinose, ribose, xylose, lactose, methyl $\alpha$-glucoside, acetate, DLmalate and citrate were not stimulatory. Glucose, sucrose and maltose were the only single carbon compounds which supported growth for more than five consecutive transfers in mineral medium. In unbuffered medium, acid was produced in the presence of glucose, galactose, sucrose, xylose and ribose. No or little acid formation was observed in the presence of fructose, mannose, arabinose, maltose, lactose, methyl $\alpha$-glucoside, mannitol, sorbitol or glycerol.

Strain $801030 / 1^{\mathrm{T}}$ grew anaerobically in the presence of nitrate with formation of nitrite and gas. No fermentative growth was demonstrated in media containing $\mathrm{L}$-arginine.

Starch was hydrolysed. Tests for hydrolysis of gelatin, casein, Tween 20 and Tween 80 all yielded negative results. No indole was produced. The strain was sensitive to bacitracin, novobiocin and anisomycin $\left(25 \mu \mathrm{g} \mathrm{m}^{-1}\right)$ and resistant to penicillin, ampicillin, rifampicin, chloramphenicol, neomycin and erythromycin (all at $50 \mu \mathrm{g} \mathrm{ml}^{-1}$ ).

The polar lipid pattern was characteristic for representatives of the genus Haloarcula, with diether derivatives of phosphatidylglycerol, the methyl ester of phosphatidylglycerophosphate and phosphatidylglycerosulfate (PG, PGP and PGS, respectively), and a single glycolipid (TGD-2, 1-O- $\left[\beta\right.$-D-glucose- $\left(1^{\prime} \rightarrow 6^{\prime}\right)$ $\alpha$-D - mannose - $\left(1^{\prime} \rightarrow 2^{\prime}\right)-\alpha$-D - glucose]-2,3-di - $O$ phytanyl-sn-glycerol) (Tindall, 1992).

The affiliation of the isolate with the genus Haloarcula was confirmed by $16 \mathrm{~S}$ rRNA sequence comparisons. At least two 16S rRNA genes were detected, designated A $(1470 \mathrm{bp})$ and $B(1471 \mathrm{bp})$. The $801030 / 1^{\mathrm{T}} \mathrm{A}$ gene showed the highest similarity $(98.2 \%)$ with the Haloarcula marismortui A gene. The B gene showed a

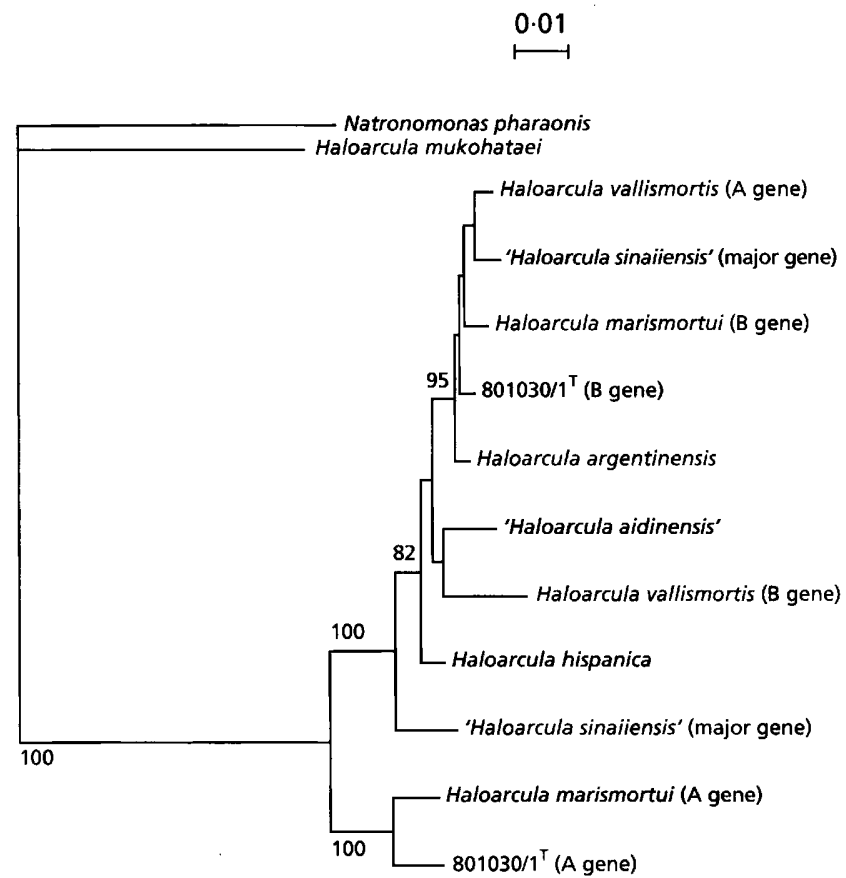

Fig. 2. Phylogenetic tree reconstruction of the genus Haloarcula by the neighbour-joining method (CLUSTAL $W$ 1.5) with $16 \mathrm{~S}$ rRNA gene sequences. The sequence data used were from the following strains (accession numbers are given in parentheses): Haloarcula vallismortis ATCC $29715^{\top}$ A gene (U17593) and B gene (U68451); Haloarcula marismortui ATCC $43049^{\top}$ A gene (X61688) and B gene (X61689); Haloarcula argentinensis CM $9737^{\top}$ (D50849); Haloarcula mukohataei JCM 9738 (D50850); 'Haloarcula sinaiiensis' ATCC 33800 major and minor gene (D14129 and 14130, respectively); and 'Haloarcula aidinensis' strain B02 (AB000563). Bootstrap values (1000 replicates) above $70 \%$ are shown. Scale bar, 0.01 expected changes per site. Natronomonas pharaonis JCM 8858 ${ }^{\top}$ (D87971) was used as the outgroup.

high degree of similarity with the Haloarcula marismortui B gene, the Haloarcula vallismortis A gene and the major gene of 'Haloarcula sinaiiensis' (99.1, 99.0 and $99.1 \%$ similarity, respectively). The sequences determined were aligned with those previously reported and used to reconstruct a phylogenetic tree. Positions with any deletions or of uncertain alignment were removed and the remaining 1440 positions were used to reconstruct the tree (Fig. 2).

DNA-DNA hybridization studies showed only low relatedness of DNA from strain $801030 / 1^{\mathrm{T}}$ with other representatives of the genus Haloarcula, the highest value being $34 \%$ with Haloarcula japonica JCM 7785 (Table 1).

The $\mathrm{G}+\mathrm{C}$ content of strain $801030 / 1^{\mathrm{T}}$ was $60 \cdot 1 \mathrm{~mol} \%$, as determined by thermal denaturation (mean of three independent determinations).

\section{DISCUSSION}

The genus Haloarcula presently consists of the following six recognized species: Haloarcula vallismortis (González et al., 1978), Haloarcula marismortui (Oren 
Table 2. Some properties differentiating strain $801030 / 1^{\top}$ from the validly described species within the genus Haloarcula

Strains: 1, strain $803010 / 3^{\mathrm{T}} ; 2$, Haloarcula vallismortis ; 3, Haloarcula marismortui $; 4$, Haloarcula hispanica; 5, Haloarcula japonica; 6, Haloarcula argentinensis; 7, Haloarcula mukohataei. +, Positive; - , negative; \pm , variable; ND, no data available. Data were derived in part from Ihara et al. (1997), Oren et al. (1988), Takashina et al. (1990) and Tindall (1992).

\begin{tabular}{|c|c|c|c|c|c|c|c|}
\hline Character & 1 & 2 & 3 & 4 & 5 & 6 & 7 \\
\hline Dominant shape & Square & Rod & Pleomorphic & Short rod & Triangular & Triangular & Short rod \\
\hline Motility & + & + & \pm & + & + & + & + \\
\hline \multicolumn{8}{|l|}{ Hydrolysis of: } \\
\hline Starch & + & + & + & + & - & ND & ND \\
\hline Gelatin & - & - & - & + & - & ND & ND \\
\hline Casein & - & - & ND & \pm & - & ND & ND \\
\hline Tween 80 & - & ND & ND & + & ND & ND & ND \\
\hline TGD-2 glycolipid & + & + & + & + & + & + & - \\
\hline DNA G $+C(\operatorname{mol} \%)$ & $60 \cdot 1$ & $64 \cdot 7$ & $61 \cdot 8$ & $62 \cdot 7$ & $63 \cdot 3$ & 62 & 65 \\
\hline
\end{tabular}

et al., 1990), Haloarcula hispanica (Juez et al., 1986), Haloarcula japonica (Takashina et al., 1990), Haloarcula argentinensis and Haloarcula mukohataei (Ihara et al., 1997). In addition, there are three species incertae sedis which are still awaiting a valid description: 'Haloarcula sinaiiensis', 'Haloarcula californiae' (Javor et al., 1982) and 'Haloarcula aidinensis' (Peijin et al., 1994; Xu et al., 1995). Strain $801030 / 1^{\mathrm{T}}$ clearly belongs to this genus. This is apparent from its polar lipid composition, which is characterized by the triglycosyl glycolipid TGD-2, found thus far only in Haloarcula species as the sole glycolipid in all species described, with the exception of Haloarcula mukohataei. The latter species was placed in the genus Haloarcula on the basis of the similarity of its $16 \mathrm{~S}$ rRNA gene sequence to the 16S rRNA sequences of other members of the genus. However, ten out of the sixteen signature bases of the genus Haloarcula are replaced by other bases in Haloarcula mukohataei (data not shown). It may therefore be justified to propose its transfer to a novel genus (Kamekura, 1999). Additional characteristics common to strain $801030 / 1^{\mathrm{T}}$ and the hitherto described species of the genus Haloarcula are its relatively high temperature optimum for growth, its ability to grow on a number of simple sugars as sole carbon and energy source, and its flat somewhat pleomorphic morphology. Also, the property of motility is shared with most other Haloarcula species. Flagellar motility has been documented in Haloarcula vallismortis (González et al., 1978), Haloarcula japonica (Takashina et al., 1990), Haloarcula hispanica (Juez et al., 1986), Haloarcula argentinensis and Haloarcula mukohataei (Ihara et al., 1997). Haloarcula marismortui has been reported as being non-motile (Tindall, 1992), but Oren et al. (1988) described motile cells rotating around their axis. The $\mathrm{G}+\mathrm{C}$ content of the DNA $(60 \cdot 1 \mathrm{~mol} \%)$ is somewhat lower than that reported for the other Haloarcula species described $(61 \cdot 8-65 \cdot 0 \mathrm{~mol} \%)$. Table 2 presents a comparison of a number of phenotypic and genotypic properties of strain $801030 / 1^{\mathrm{T}}$ and the validly described Haloarcula species.

Strain $801030 / 1^{\mathrm{T}}$ contained more than one nonidentical 16S rRNA gene. Also this property is common to representatives of the genus Haloarcula. Thus, Haloarcula vallismortis, Haloarcula marismortui, and 'Haloarcula sinaiiensis' were reported to possess at least two heterogeneous 16S rRNA genes (Kamekura, 1999; Mylvaganan \& Dennis, 1992). Both sequences confirm the affiliation of the strain with the genus Haloarcula, with a particularly high similarity with Haloarcula marismortui, Haloarcula vallismortis, and 'Haloarcula sinaiiensis' (Fig. 2). Unfortunately, no complete 16S rRNA sequence of Haloarcula japonica has been published. Aligning the available partial sequence (D28872), encompassing 1424 bases including 88 where the base assignment was ambiguous, yielded similarity values of 96.3 and $94.4 \%$ with the $801030 / 1^{\mathrm{T}} \mathrm{A}$ and $\mathrm{B}$ genes, respectively.

DNA-DNA hybridization experiments (Table 1) showed only low degrees of relatedness of strain $801030 / 1^{\mathrm{T}}$ with the recognized Haloarcula species, as well as with other halophilic archaea. Notably, the hybridization with DNA from Haloarcula marismortui, the organism showing the closest phylogenetic relationship based on 16S rRNA sequences, was extremely low. The highest DNA-DNA relatedness (34\%) was measured with Haloarcula japonica DNA. However, this value is still far below the consensus value of $70 \%$ delineating the species level (Wayne et al., 1987). Such low DNA-DNA hybridization values do not provide any significant information on phylogenetic relationships.

The data presented above suggest that the square halophilic archaeon strain $801030 / 1^{\mathrm{T}}$ belongs to the genus Haloarcula, but cannot be placed in any of the recognized species within that genus. Therefore, we propose a new species, Haloarcula quadrata, to accom- 
modate this strain. For the time being, the species description is necessarily based on a single strain, as no additional square strains have been isolated and preserved to the best of our knowledge.

The finding that strain $801030 / 1^{\mathrm{T}}$ is a Haloarcula, and so are the 'box-shaped' isolates originating from attempts to isolate square bacteria (Javor et al., 1982), does not imply that all square bacteria, including the gas vacuoles containing cells first described by Walsby (1980) and since found ubiquitously in hypersaline environments, are members of the Haloarcula genus. Most probably this is not the case, as shown by analyses of communities of square bacteria collected from their natural habitats. A sample of material from the Gavish Sabkha rich in square bacteria was analysed by fast atom bombardment-mass spectrometry. In addition to PG, PGP and PGS, a trisaccharide glycolipid and its sulfated derivative were found that were identical to the TGD-1 (1-O- $\left[\beta\right.$-D-galactose- $\left(1^{\prime} \rightarrow\right.$ $\left.6^{\prime}\right)$ - $\alpha$-D-mannose-( $\left.1^{\prime} \rightarrow 2^{\prime}\right)-\alpha$-D-glucose]-2,3-di- $O$-phytanyl-sn-glycerol) and S-TGD-1 (1- $O$ - $[\beta$-D-galactose$\left(3^{\prime}-\mathrm{SO}_{3} \mathrm{H}\right)-\left(1^{\prime} \rightarrow 6^{\prime}\right)-\alpha-\mathrm{D}-$ mannose $-\left(1^{\prime} \rightarrow 2^{\prime}\right)-\alpha-\mathrm{D}-$ glucose]-2,3-di- $O$-phytanyl-sn-glycerol) glycolipids of Halobacterium salinarum (Fredrickson et al., 1989). Polar lipid analysis of a brine sample from a saltern crystallizer pond in Eilat, Israel, in which the majority of the cells showed a square to trapezoid flat shape with gas vesicles, yielded PG, PGP, PGS and a single glycolipid, chromatographically identical with SDGD-1 (1-O-[ $\beta$-D-mannose- $\left(6^{\prime}-\mathrm{SO}_{3} \mathrm{H}\right)-\left(1^{\prime} \rightarrow 2^{\prime}\right)-\alpha-\mathrm{D}-$ glucose]-2,3-di- $O$-phytanyl-sn-glycerol), the major glycolipid found in all Haloferax species (Oren et al., 1996). Therefore, it may tentatively be concluded that these square bacteria contained S-DGD-1 as their (principal) glycolipid. Thus, it may be assumed that the square morphology has originated in more than one genus of halophilic archaea. Whatever their taxonomic affiliation might be, the gas-vacuole-containing type of square bacteria observed by Walsby (1980), and described as non-motile (Grant \& Larsen, 1989), has thus far defied all microbiologists' attempts to isolate them.

\section{Description of Haloarcula quadrata (Oren, Ventosa, Gutiérrez and Kamekura) sp. nov.}

Haloarcula quadrata (qua.dra'ta. L. fem. adj. quadrata square).

Gram-negative. Predominantly square-shaped, pleomorphic, flat cells, $2-3 \mu \mathrm{m}$, motile by means of one or more flagella. Colonies small, entire, smooth and redorange. Chemo-organotrophic. Growth occurs in the presence of $2 \cdot 7-4 \cdot 3 \mathrm{M} \mathrm{NaCl}$. At least $50-100 \mathrm{mM}$ $\mathrm{Mg}^{2+}$ is required for optimal growth and maintenance of the square morphology. Optimum temperature for growth is $53{ }^{\circ} \mathrm{C}$; no growth observed above $55^{\circ} \mathrm{C}$. Growth occurs on glucose, sucrose and maltose as single carbon and energy sources. Growth stimulation further observed by galactose, mannitol, sorbitol, glycerol, succinate and pyruvate. Acid is produced in the presence of glucose, galactose, sucrose, xylose or ribose. Grows anaerobically in the presence of nitrate with formation of nitrite and gas. No anaerobic growth in the presence of arginine. Starch hydrolysed. No hydrolysis of gelatin, casein, Tween 20 or Tween 80 . Indole is not produced. Oxidase- and catalase-positive. Polar lipids are phosphatidylglycerol, the methyl ester of phosphatidylglycerophosphate, phosphatidylglycerosulfate and a single glycolipid (TGD-2). Susceptible to bacitracin, novobiocin and anisomycin $\left(25 \mu \mathrm{g} \mathrm{ml}^{-1}\right)$. Resistant to penicillin, ampicillin, rifampicin, chloramphenicol, neomycin and erythromycin $\left(50 \mu \mathrm{g} \mathrm{ml}^{-1}\right)$. The $\mathrm{G}+\mathrm{C}$ content of the type strain is $60.1 \mathrm{~mol} \%\left(T_{\mathrm{m}}\right.$ method). The type strain, $801030 / 1^{\mathrm{T}}$, was isolated from a brine pool in the Sinai peninsula, Egypt, and is deposited in the DSMZ - Deutsche Sammlung von Mikroorganismen und Zellkulturen, Braunschweig, Germany, as strain DSM $11927^{\mathrm{T}}$. The 16S rRNA sequence accession numbers of the type strain are AB010964 and AB010965.

\section{ACKNOWLEDGEMENTS}

This study was supported by grant no. 95-00027 from the United States-Israel Binational Science Foundation (BSF, Jerusalem, Israel) (to A.O.), grant BI04-CT96-Ф488 (Extremophiles as Cell Factories) from the European Commission, grants PB93-0920 and BI097-1876-CE from the Spanish Ministerio de Educatión y Ciencia, and from the Junta de Andalucia (to A.V.). We thank Martin Kessel (Bethesda, MD, USA) for supplying the culture of strain $801030 / 1^{\mathrm{T}}$ and Dieter Oesterhelt (Martinsried, Germany) for encouraging our efforts toward a formal description of the species.

\section{REFERENCES}

Alam, M., Claviez, M., Oesterhelt, D. \& Kessel, M. (1984). Flagella and motility behaviour of square bacteria. $E M B O J \mathbf{3}$, 2899-2903.

Cohen, S., Oren, A. \& Shilo, M. (1983). The divalent cation requirement of Dead Sea halobacteria. Arch Microbiol 136, 184-190.

De Ley, J. \& Tijtgat, R. (1970). Evaluation of membrane filter methods for DNA-DNA hybridization. Antonie Leeuwenhoek 36, 461-474.

Ferragut, C. \& Leclerc, H. (1976). Étude comparative des méthodes de détermination du $T_{\mathrm{m}}$ de l'ADN bactérien. Ann Microbiol (Paris) 127, 223-235.

Fredrickson, H. L., Rijpstra, W. I. C., Tas, A. C., van der Greef, J., LaVos, G. F. \& de Leeuw, J. W. (1989). Chemical characterization of benthic microbial assemblages. In Microbial Mats: Physiological Ecology of Benthic Microbial Communities, pp. 455-468. Edited by Y. Cohen \& E. Rosenberg. Washington, DC: American Society for Microbiology.

González, C., Gutiérrez, C. \& Ramirez, C. (1978). Halobacterium vallismortis sp. nov. An amylolytic and carbohydrate-metabolizing extremely halophilic bacterium. Can J Microbiol 24, 710-715.

Grant, W. D. \& Larsen, H. (1989). Extremely halophilic archaeobacteria. Order Halobacteriales ord. nov. In Bergey's Manual of Systematic Bacteriology, pp. 2216-2233. Edited by N. Pfennig. Baltimore: Williams \& Wilkins. 
Guixa-Boixareu, N., Calderón-Paz, J. I., Heldal, M., Bratbak, G. \& Pedrós-Alió, C. (1996). Viral lysis and bacterivory as prokaryotic loss factors along a salinity gradient. Aquat Microb Ecol 11, 215-227.

Gutiérrez, C. \& González, C. (1972). Method for simultaneous detection of proteinase and esterase in extremely halophilic bacteria. Appl Microbiol 24, 516-517.

Ihara, K., Watanabe, S. \& Tamura, T. (1997). Haloarcula argentinensis sp. nov. and Haloarcula mukohataei sp. nov., two new extremely halophilic archaea collected in Argentina. Int $J$ Syst Bacteriol 47, 73-77.

Javor, B., Requadt, C. \& Stoeckenius, W. (1982). Box-shaped halophilic bacteria. $J$ Bacteriol 151, 1532-1542.

Johnson, J. L. (1994). Similarity analysis of DNAs. In Methods for General and Molecular Bacteriology, pp. 655-681. Edited by P. Gerhardt, R. G. E. Murray, W. A. Wood \& N. R. Krieg. Washington, DC: American Society for Microbiology.

Juez, G., Rodriguez-Valera, F., Ventosa, A. \& Kushner, D. J. (1986). Haloarcula hispanica spec. nov. and Haloferax gibbonsii spec. nov., two new species of extremely halophilic archaebacteria. Syst Appl Microbiol 8, 75-79.

Kamekura, M. (1999). Diversity of members of the family Halobacteriaceae. In Microbiology and Biogeochemistry of Hypersaline Environments, pp. 13-25. Edited by A. Oren. Boca Raton: CRC Press.

Kamekura, M. \& Seno, Y. (1993). Partial sequence of the gene for a serine protease from a halophilic archaeon Haloferax mediterranei $\mathrm{R} 4$, and nucleotide sequences of 16S rRNA encoding genes from several halophilic archaea. Experientia 49, 503-513.

Marmur, J. (1961). A procedure for the isolation of deoxyribonucleic acid from microorganisms. J $\mathrm{Mol}$ Biol 3, 208-219.

Marmur, J. \& Doty, P. (1962). Determination of the base composition of deoxyribonucleic acid from its thermal denaturation temperature. $J$ Mol Biol 5, 109-118.

Mylvaganan, S. \& Dennis, P. P. (1992). Sequence heterogeneity between the two genes encoding 16S rRNA from the halophilic archaebacterium Haloarcula marismortui. Genetics 130, 399410.

Oren, A. (1994). The ecology of the extremely halophilic archaea. FEMS Microbiol Rev 13, 415-440.

Oren, A., Lau, P. P. \& Fox, G. E. (1988). The taxonomic status of 'Halobacterium marismortui' from the Dead Sea: a comparison with Halobacterium vallismortis. Syst Appl Microbiol 10, 251-258

Oren, A., Ginzburg, M., Ginzburg, B. Z., Hochstein, L. I. \& Volcani, B. E. (1990). Haloarcula marismortui (Volcani) sp. nov., nom. rev., an extremely halophilic bacterium from the Dead Sea. Int $J$ Syst Bacteriol 40, 209-210.

Oren, A., Duker, S. \& Ritter, S. (1996). The polar lipid composition of Walsby's square bacterium. FEMS Microbiol Lett 138, 135-140.

Oren, A., Ventosa, A. \& Grant, W. D. (1997). Proposal of minimal standards for the description of new taxa in the order Halobacteriales. Int J Syst Bacteriol 47, 233-238.

Owen, R. J. \& Hill, L. R. (1979). The estimation of base compositions, base pairing and genome size of bacterial deoxyribonucleic acids. In Identification Methods for Microbiologists, 2nd edn, pp. 217-296. Edited by F. A. Skinner \& D. W. Lovelock. London: Academic Press.

Owen, R. J. \& Pitcher, D. (1985). Current methods for estimating DNA base composition and levels of DNA-DNA hybridization. In Chemical Methods in Bacterial Systematics, pp. 67-93. Edited by M. Goodfellow \& E. Minnikin. London: Academic Press.

Parkes, K. \& Walsby, A. E. (1981). Ultrastructure of a gasvacuolate square bacterium. J Gen Microbiol 126, 503-506.

Peijin, Z., Yi, X., Changsong, X., Yunquing, M. \& Hongdi, L. (1994). New species of Haloarcula. Acta Microbiol Sin 34, 89-95.

Stoeckenius, W. (1981). Walsby's square bacterium: fine structure of an orthogonal procaryote. J Bacteriol 148, 352-360.

Takashina, T., Hamamoto, T., Otozai, K., Grant, W. D. \& Horikoshi, K. (1990). Haloarcula japonica sp. nov., a new triangular halophilic archaebacterium. Syst Appl Microbiol 13, 177-181.

Tindall, B. J. (1992). The family Halobacteriaceae. In The Prokaryotes, 2nd edn, pp. 768-808. Edited by A. Balows, H. G. Trüper, M. Dworkin, W. Harder \& K.-H. Schleifer. New York: Springer.

Torreblanca, M., Rodriguez-Valera, F., Juez, G., Ventosa, A., Kamekura, M. \& Kates, M. (1986). Classification of nonalkaliphilic halobacteria based on numerical taxonomy and polar lipid composition, and description of Haloarcula gen. nov. and Haloferax gen. nov. Syst Appl Microbiol 8, 89-99.

Torrella, F. (1986). Isolation and adaptive strategies of haloarculae to extreme hypersaline habitats. In Abstracts of the Fourth International Symposium on Microbial Ecology, p. 59. Ljubljana: Slovene Society for Microbiology.

Walsby, A. E. (1980). A square bacterium. Nature 283, 69-71.

Wayne, L. G., Brenner, D. J., Colwell, R. R. \& 9 other authors (1987). International Committee on Systematic Bacteriology. Report of the ad hoc committee on reconciliation of approaches to bacterial systematics. Int J Syst Bacteriol 37, 463-464.

Xu, Y., Liu, H. \& Zhou, P. (1995). Nucleotide sequence of the $16 \mathrm{~S}$ rRNA from an archaea, Haloarcula aidinensis strain B2. Acta Microbiol Sin 35, 77-85. 